\title{
Technology Acceptance Model and its Scope of Application in Teaching Practices at Secondary Level
}

\author{
Shahida Praveen ${ }^{*}$
}

\begin{abstract}
Technology Acceptance Model (TAM) was developed by Davis in 1989. Still this model is most popular to predict anyone's technology intention to use it. So this study used TAM to find out its scope of application in Pakistani context. Secondary level education is a big milestone in any student's learning career. To know about the use of Technology is considered important literacy skill in twenty first century, so this study aimed to explore the scope of Technology Acceptance Model in teaching practices at Pakistani secondary level institutes. The population of this study was delimited to the secondary level Public school teachers of district Gujranwala (Punjab). According to Punjab School Education Department, 4921 teachers were working in District Gujranwala; 2497male teachers and 2424 female teachers at secondary level. So 500 teachers, 250 male and 250 female were randomly selected as participants of this study. This study was descriptive research. Researcher developed a tool on the constructs of TAM. This tool was consisted of 20 statements on seven point Likert scale. Researcher observed teaching practices of participants in learning environment also. During observations some of their students were interviewed to triangulate the data. Researcher used mixed methods approach to analyze the data. This study proved that Perceived usefulness (PU) plays significant role in developing attitude towards use of technology. Previous experience and technology aversions or harmonies were influencing the perceived ease of use (PEOU) and then behavior intension (BI) to use technology. The findings of this study proved that teachers should be trained and facilitated to integrate technology in teaching learning process so teachers will be able to better perform. Moreover this study contributes to the related literature and provides new dimensions to future researches.
\end{abstract}

\footnotetext{
* Principal Public high school Saharan Chattha, Gujranwala Pakistan
} 
Keywords: technology acceptance model, literacy skills, perceived usefulness, perceived ease of use

\section{Introduction}

With the invention of computer, all fields of life had been affected in last four decades of previous century. Interaction between humans and computers is affected by quite a number of human factors and its characteristics (whitely, 1997). To predict human attitude towards use of technology had gained more attention of researchers in last two decades of previous century. One of them was Davis, who developed a technology acceptance model (TAM) to predict human behavior intention to use of technology in 1989. This model was based on The Theory of Reasoned Action (TRA) and The Theory of Planned Behavior (TPB).

With the advent of this century the teaching practices have been faced more challenges in learning environment to satisfy not only the students but also their parents. One of the most common challenges for teaching practices is to integrate technology in teaching process. The integration of learning technologies into high school classroom is being promoted and supported around the world (Cope\& Ward, 2002). So there is a great need to identify the technology perception found in teachers due to the requirements of twenty first century. This study aimed to identify secondary school teachers' technology perception applying TAM in Pakistani context.

\section{Review Related Literature}

TAM had been theoretical extended in further researches, but still this model is most popular to predict any one's technology intention to use it. So researcher used it to find out its scope of application among secondary school teachers in Pakistani context. This model has five constructs, named external variables, perceived usefulness (PU), perceived ease of use (PEOU), attitude towards use (ATU), and behavioral intention (BI). Here is given structure of this model according to Davis (1989) in Figure 1. 


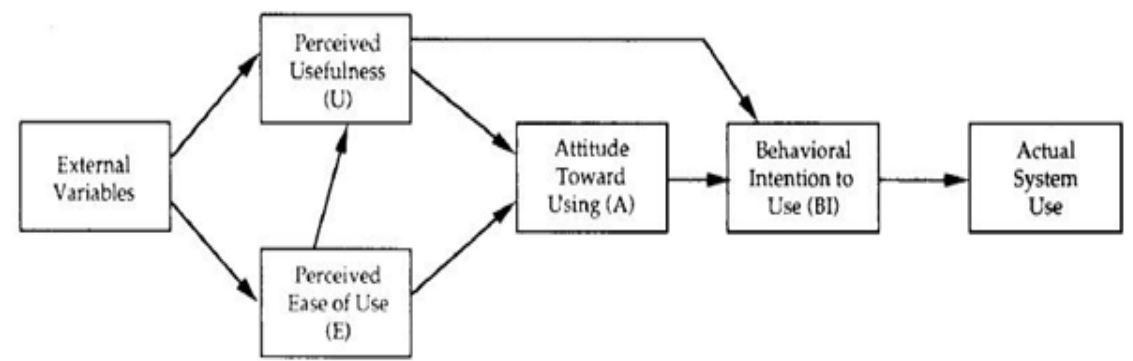

Figure 1. Davis, 1989

\section{External Variable}

These variables vary situation to situation or person to person. Such as Previous experiences, prior knowledge, demographical variables, availability of resources, self-motivation and highly dedication are all external variables. Individual differences behave like external variables. In this study researcher focused on two external variables, Subjective norms (SN) and Facilitating conditions (FC), while age and gender were kept moderate. According to TAM (Davis, 1989) external variables influence Perceived usefulness (PU) and Perceived ease of use (PEOU). The researcher intended to identify influences of subjective norms (SN) and facilitating conditions (FC) in perceived usefulness (PU) and perceived ease of use (PEOU) among secondary school teacher regarding use of technology in learning environment as well as real life. Subjective norm (SN) is believed to influence intention to use because people may choose to perform behavior, even if they are not themselves favorable toward the behavior or the consequences (Venkatesh and Davis, 2000).

\section{Perceived Usefulness (PU)}

According to TAM (Davis, 1989) perceived usefulness (PU) affects in the formation of attitude towards use (ATU) and behavioral intention (BI) to use of technology in actual. This study aimed to find out role of Perceived usefulness (PU) in the development of attitude towards use (ATU) and behavioral intention (BI) to use of technology among teachers at secondary level. Perceived usefulness (PU) was considered professionally valuable and important in teaching practices with the connection of using technology in learning environment to enhance students' learning motivations and improve their learning styles. 


\section{Perceived Ease of Use (PEOU)}

Perceived ease of use (PEOU) is mostly influenced by previous experiences with technology or its training and willingness to use technology. This construct of TAM (Davis, 1989) was considered significant in developing technology perception of usefulness and attitude towards use which had proved in mostly related previous researches. Technology aversion or harmony plays very important role in PEOU. So researcher aimed to identify PEOU found among secondary school teachers regarding to use of technology in Pakistani public sector.

\section{Attitude Towards Use (ATU)}

According to TAM (Davis, 1989) perceived usefulness (PU) and perceived ease of use (PEOU) play significant role in developing or forming the attitude towards use (ATU). In this study researcher's intention was to explore which construct of the model more influenced the attitudes of secondary school teachers in Pakistan towards use of technology.

\section{Behavioral Intention (BI)}

It is an urge to perform specific pattern of behavior in particular situation. In this study, it refers to perception of technology and using it in real learning situation to integrate technology into teaching practices. The teachers play a key role to build any nation whether they use teacher centered approach or student centered approach in their learning environment.

Teachers are commonly considered as role model for students especially in school level education. In Pakistan, teachers have been facing attitude problems to accept technology for many years like other developing countries at secondary level education. Same attitude problem was found in the teachers of developed countries during late nineties. So a lot of studies were focused on it. According to Munday, Kupsczynski \& Kee (2012) there is lot of research on the views of teacher's about technology use in the classroom. Even though many teachers use a variety of social media as part of their daily personal life, this use does not automatically translate into classroom protocols and practices (Jones, 2012). Teachers at secondary level involves actively at social media such as face book, what's apps and viber to communicate 
in their social circle but this communication does not become fruitful in teaching practices until perceived usefulness of technology acceptance is not identified.

The collective efforts of whole teaching staff with the involvement of Head teacher are mostly considered important to provide facilitating environment for using technology in teaching practices. This collaboration is highly required to integrate technology in teaching methodology. This study aimed to find out perceived usefulness (PU) among secondary school teachers regarding technology acceptance in Pakistani context. According to International Reading Association (2009), that literacy and use of technology in classrooms are highly focused in this century. Therefore, in order to implement ICT in teaching and learning we need a better understanding of the beliefs that influence teachers in deciding to use technology or not (Kriek \& Stols 2010). Technology acceptance in teaching practices has been gaining more attention for last three decades.

Realizing the effect of ICT on the workplace and everyday life, today's educational institutions try to restructure their educational curricula and classroom facilities, in order to bridge the existing technology gap in teaching and learning (Bobbing \&Anode, 2012). It specifies the relationships among perceived usefulness, perceived ease of use, attitude towards use, and behavioral intention to use technology (Toe, 2011).

\section{Methodology}

This study was descriptive in nature. Mixed method approach was used in this study. Mixed method is a research approach, in which researchers collect, analyze, and integrate both quantitative and qualitative data in a single study (Cresswell, 2013). To overcome the deficiencies from one way of data collection, researcher applied data triangulation techniques; survey method, observations and interview method. The Technology acceptance model (Davis, 1989) was applied adding two external variables Subjective norms (SN) and facilitating conditions (FC) in this research. (Figure 2) 


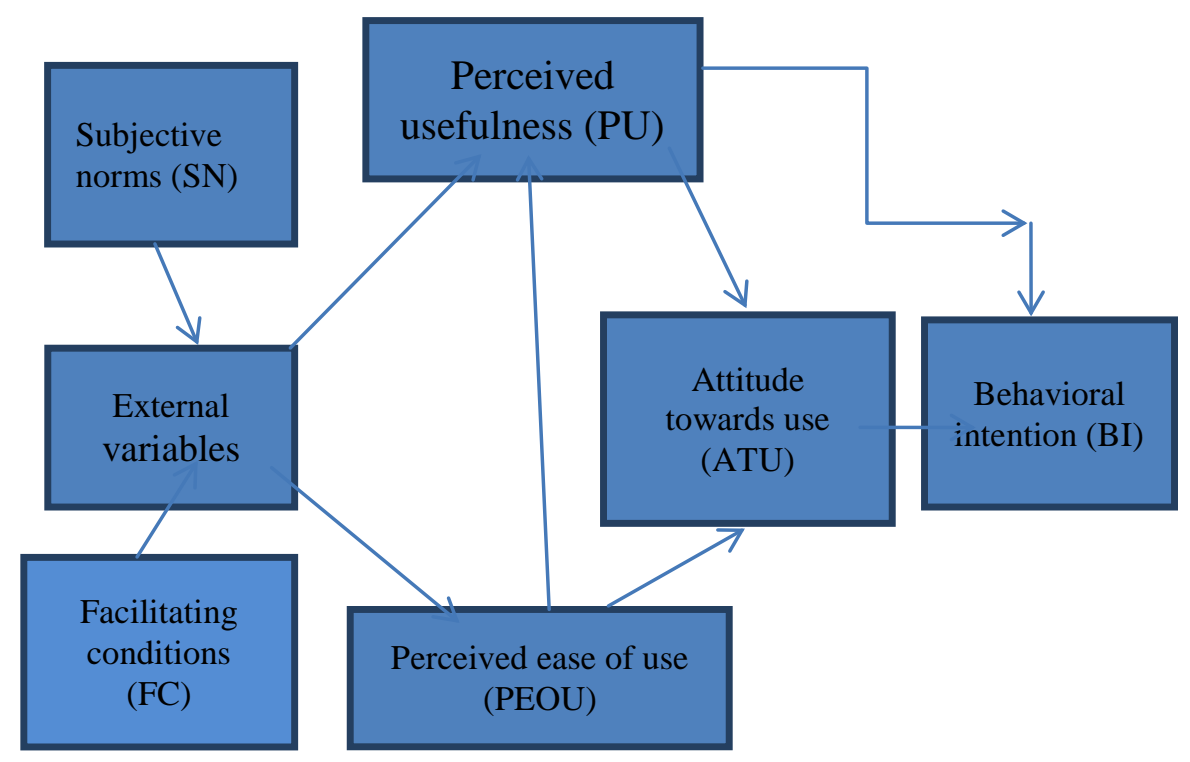

Figure 2. Technology acceptance model

Data was collected through using survey method. Researcher observed teaching practices of participants in learning environment also. During observations some of their students were interviewed to triangulate the data.

\section{Population \& Participants of Study}

This study was delimited to one district (Gujranwala) of province Punjab (Pakistan). The secondary level public school teachers were considered as population of this research work. According to Punjab School Education Department, 4921 teachers were working in District Gujranwala; 2497male teachers and 2424 female teachers at secondary level. The participants of study were randomly selected from different secondary level public schools of Gujranwala. 500 secondary school teachers; 250 male teachers and 250 female teachers were randomly selected as participants of study. They were equated on three age groups, given detail below in tabulated form. 
Table 1

Representation of age groups of participants

\begin{tabular}{lcc}
\hline Sr. & Age group of & Representative \% of participants \\
No & participants & \\
\hline 1 & 25 years to 35 years & $40 \%$ \\
2 & 35 years to 45 years & $40 \%$ \\
3 & 45 years to 55 years & $20 \%$ \\
\hline
\end{tabular}

Demographical variables such as Gender and Age were kept moderate in this study.

\section{Instrumentation of Study}

Tool of this study was adapted from reviewing related literature and previous researches. The tool was consisted twenty items based on the five constructs of technology acceptance model. First construct was External variables based on two sub constructs, Subjective Norms (SN) and Facilitating conditions (FC). Four items for SN and four items for FC were used in tool. Second construct was perceived usefulness (PU) and four items were used to identify it. Third construct of theory was perceived ease of usefulness (PEOU) and four items were used in tool for it. Fourth construct was attitude towards use (ATU) two items were used to explore it. Fifth construct was behavior intention (BI) two items were used for it. Its detail is given in tabulated form also (Table 2).

Table 2

\begin{tabular}{ll}
\hline \multicolumn{1}{c}{ Constructs } & \multicolumn{1}{c}{ No. of items } \\
\hline Perceived Usefulness (PU) & 4 items \\
& First four statements in tool \\
Perceived Ease of Use (PEOU) & 4 items \\
& No. 5,6,7\&8 statements \\
Subjective Norm(SN) & 4 item \\
& No. 9, 10,11,\&12 statements \\
Facilitating Condition (FC) & 4 items \\
& No.13,14,15 \&16 statements \\
Attitude towards Use (ATU) & 2 items \\
& No.17 \& 18 Statements \\
Behavioral Intention(BI) & 2 items \\
& No.19 \&20 statements in tool \\
\hline
\end{tabular}


The responses were required on seven point Lickert scale, (1) extremely agree, (2) mostly agree, (3) somewhat agree, (4) neutral, (5) somewhat disagree, (6) mostly disagree and (7) extremely disagree. Data was collected through using survey method. Researcher observed teaching practices of participants in learning environment also. During observations some of their students were interviewed to triangulate the data.

\section{Data Analysis}

A convergent parallel mixed methods design was used in this study. According to Wittink et al. (2006), a convergent parallel mixed methods design is such type of design in which qualitative and quantitative data are collected in parallel, analyzed separately, and then merged. Quantitative analyses was used to analyze the gathered responses on seven point Lickert scale developed tool, while gathered information from observing the teaching practices and interviewing to the students of participants were analyzed qualitatively. Researcher interpreted the responses of participants with the help of charts and discussed it in detail.

\section{Results \& Interpretation}

According to research model of this study, Subjective Norms (SN) was considered as external variable, so frequency of participants' responses were given below in a chart of three columns (SN,PU,PEOU). (Figure 4)

External variable (SN)

Perceived Usefulness (PU)

External variable (SN) perceived ease of usefulness (PEOU) 


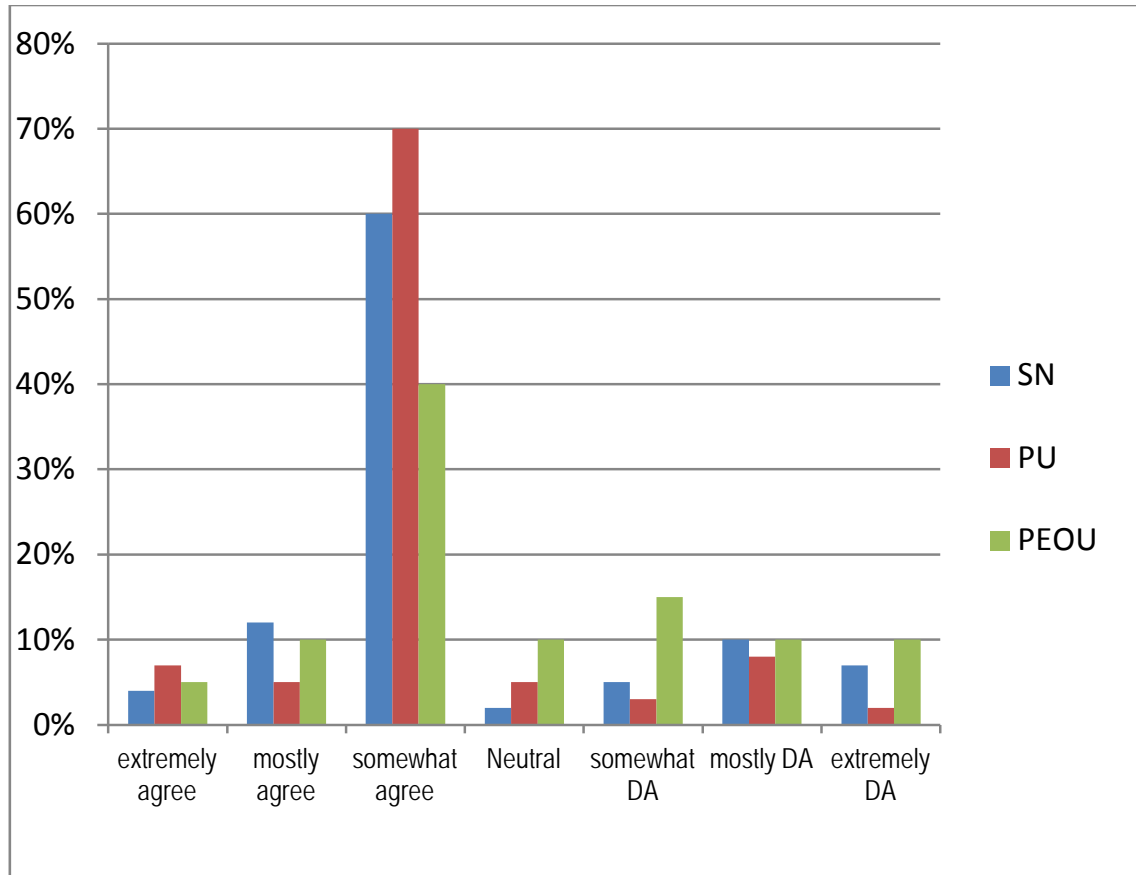

Figure 4.

Four items in developed tool were used to identify subjective Norms (SN) as external variables. SN varied teacher to teacher due to the individual differences found among them. More than seventy percent responses were obtained positive responses in regarding four items of SN. Almost eighty percent positive responses of participants in four items of PU were shown that link of SN with PU mattered a lot as compare to PEOU which having fifty five percent positive responses in same number of items(four).

Responses of participants represented that SN played important role in Perceived Usefulness (PU) and as well as Perceived Ease of Usefulness (PEOU) for technology acceptance. High positive responses in PU proved that teachers considered it more important rather than PEOU according to this study. Teachers were well aware about the professional importance of technology acceptance. During the observations of their teaching practices, researcher explored that some teachers had been facing computer aversions or dis harmony to some extent due to lack of previous trainings or experiences with technology. But they wanted to tackle it with extra training and time limit for computer usage in school timings. Some senior secondary teachers, 
above the age of fifty years had shown lack of interest in technology acceptance saying that there was no need to use of technology due to near the completion of teaching services and soon would be retired.

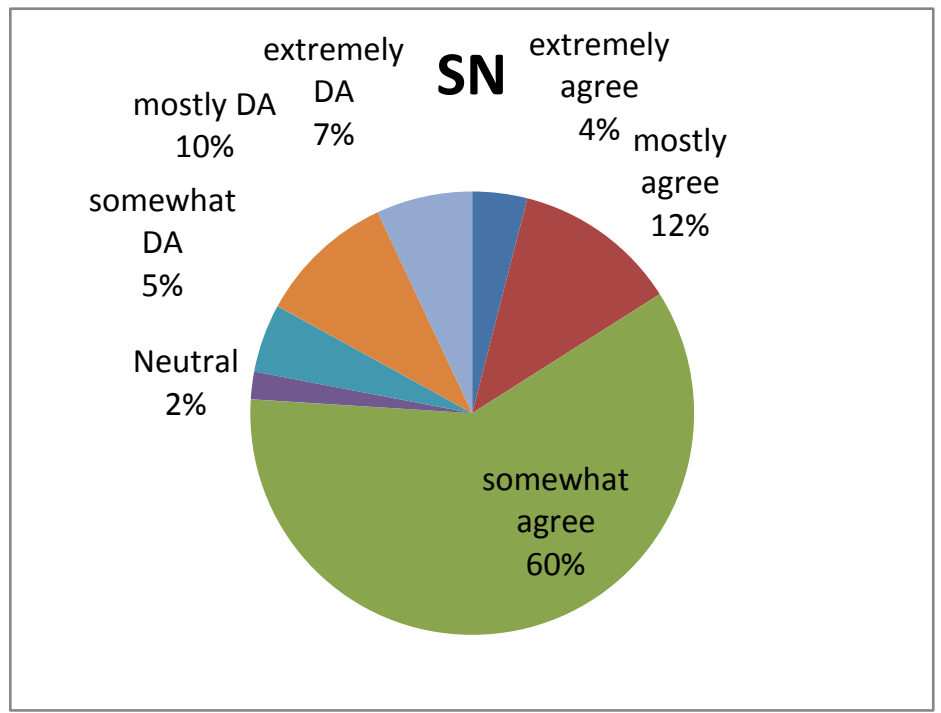

Figure 5. Participants’ responses on four items of SN

Second External variable was facilitating conditions (FC), four items of tool were used to take responses of Participants in this regard. Representation of participants' responses was given below in figure 6 . Here is comparison of responses in the constructs of Technology acceptance model, FC, PU and PEOU.

External variables (FC) $\longrightarrow \quad$ Perceived usefulness (PU) External variables (FC) $\longrightarrow$ Perceived ease of usefulness (PEOU)

Responses on FC identified that participants were facing adjustment problems with technology due to lack of available resources. All secondary schools had IT labs, but 65\% participants responded in neutral, somewhat DA, mostly DA and extremely DA, when they were asked about availability of skilled person on facing problem in use of computer, or enough time to improve computer skills. So there is great need to provide them a skilled person for computer training to integrate technology in teaching practices during school timings.

An IT specialist has been working as secondary school teacher in every school of Punjab (Pakistan) since 2009 due to launching IT Lab 
Project in all secondary level schools. According to Cem chuddar, (2014) IT Teachers are not only responsible for executing basic courses on the use of information and communication technologies but they also play a role as consultant in the integration of technology within their assigned schools. But that teacher can hardly manage all students of school to teach computer skills. Other secondary teachers cannot be facilitated due to lack of enough time. Even when they were asked about provision of any kind of assistance from skilled colleagues, most of them respond in negative. The collective efforts of whole teaching staff with the involvement of Head teacher are mostly considered important to provide facilitating environment for using technology in teaching practices. This collaboration is highly required to integrate technology in teaching methodology of secondary school teachers in Pakistani scenario.

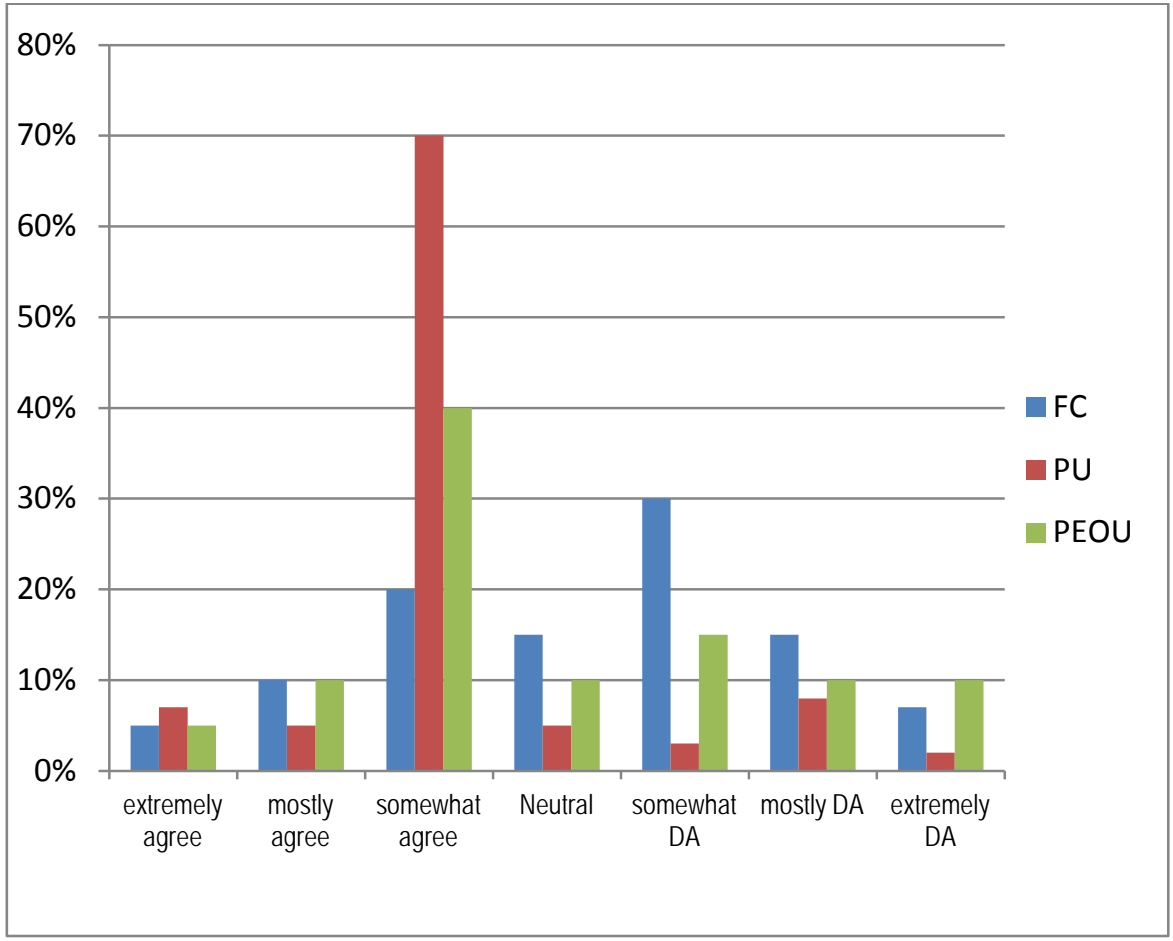

Figure 6. 


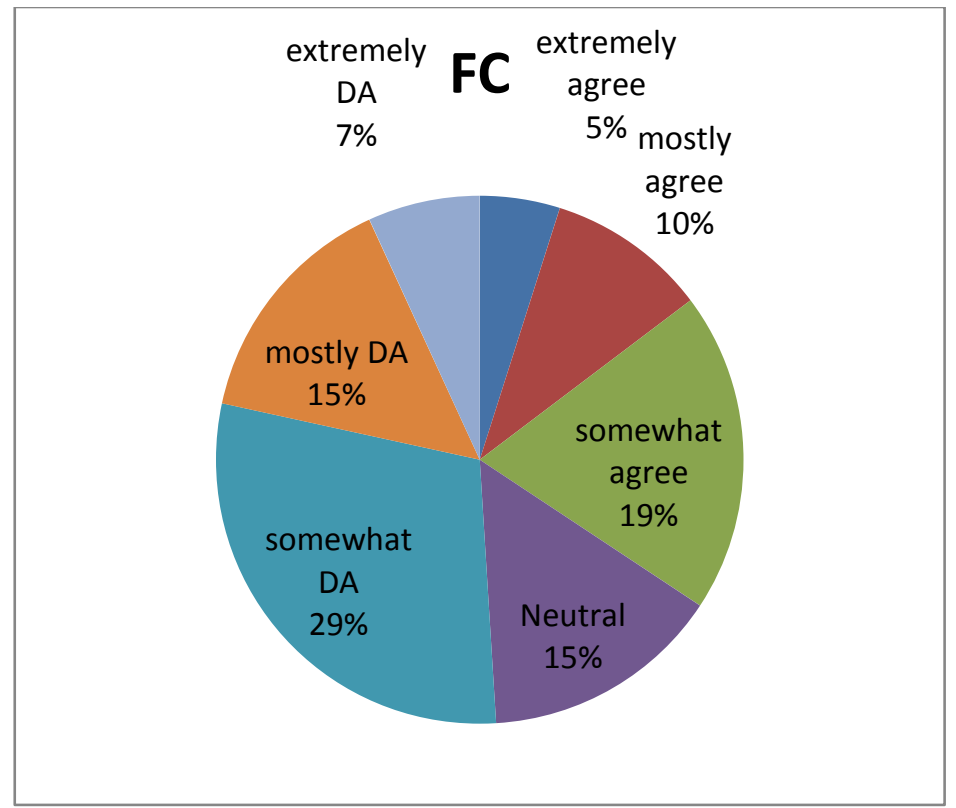

Figure 7. Participants' responses in four items of FC

Perceived ease of use (PEOU)

Perceived Usefulness (PU)

Perceived ease of Use (PEOU)

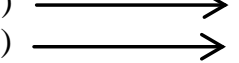
Attitude towards to Use (ATU)

TAM postulates that two beliefs, Perceived Usefulness (PU) and Perceived Ease of Use (PEOU), are important determinants of technology acceptance (Davis et al., 1989). The model specifies three belief factors that are salient in the context of information technology usage and acceptance: perceived usefulness (PU), perceived ease of use (PEOU), and attitude towards usage (ATU) (Ajzen \& Fishbein, 2000). In this study almost fifty five percent positive responses of PEOU were influencing PU and ATU. (Figure 8) Four items were used in tool to explore PEOU among secondary school teachers. Low positive responses of participants in PEOU to some extent as compare to PU and ATU proved that teachers were facing problems to use technology easily and efficiently in their teaching practices, while high rate of positive responses in PU and ATU were shown that teachers considered the use of technology as integral part of their professional life. Perceived usefulness (PU) played more significant role in formation of attitude towards use of technology rather than perceived ease of use according to this study. (Figure 10) 


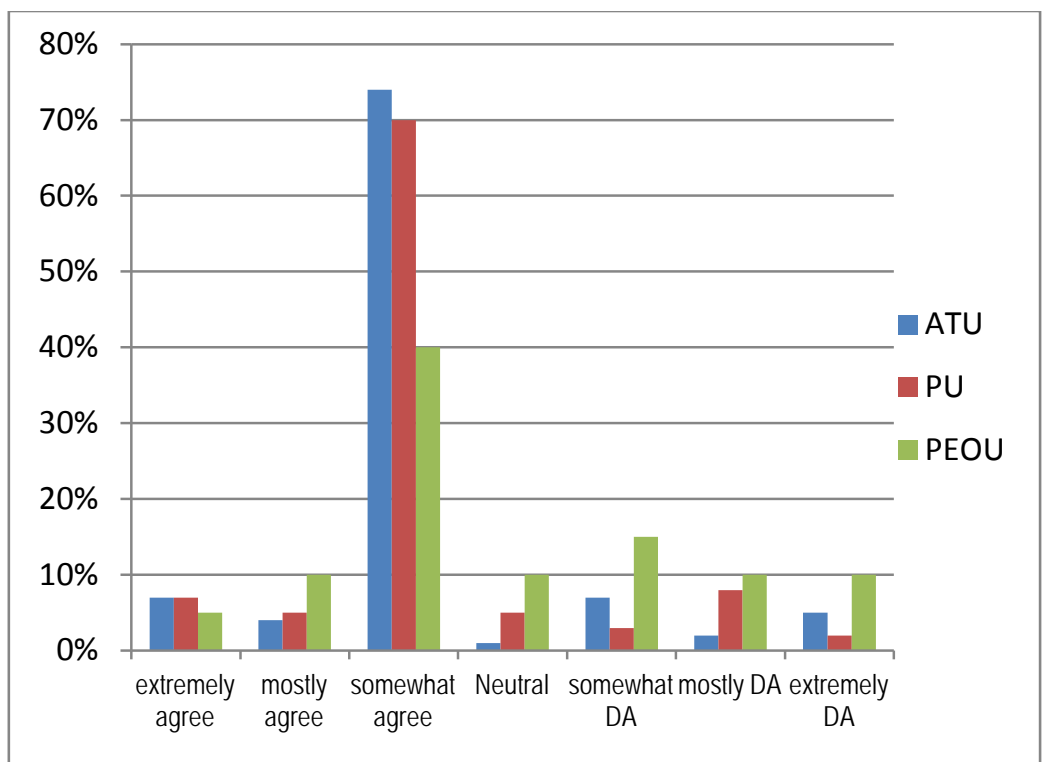

Figure 8.

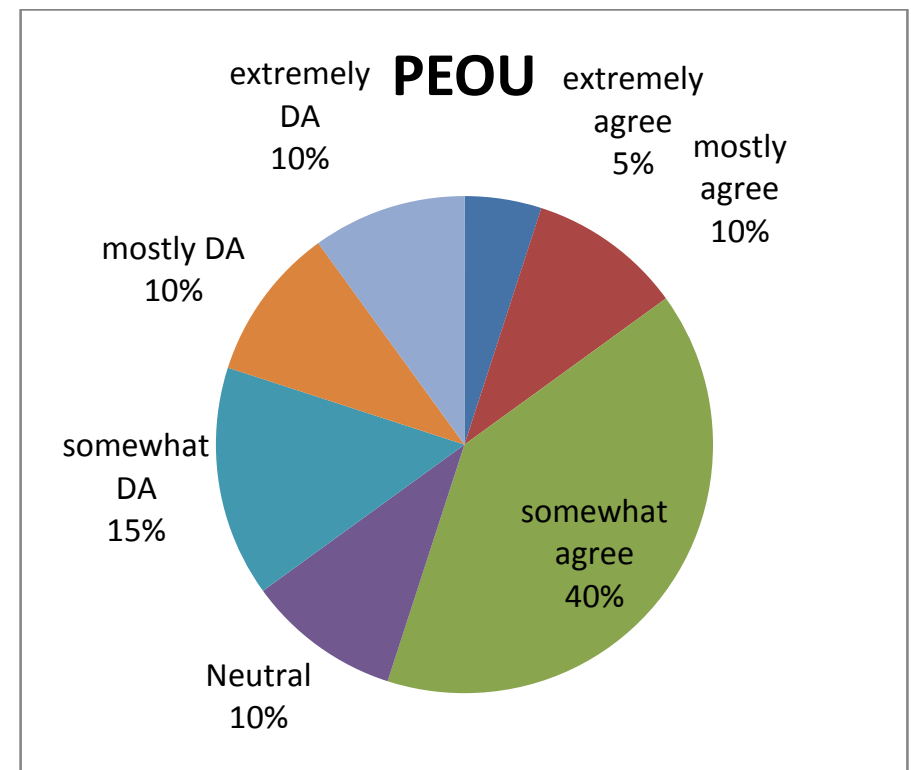

Figure 9. Participants' responses on four items of PEOU

Perceived Usefulness (PU) Perceived Usefulness (PU)
Attitude towards to Use (ATU) Behavior Intention (BI) 


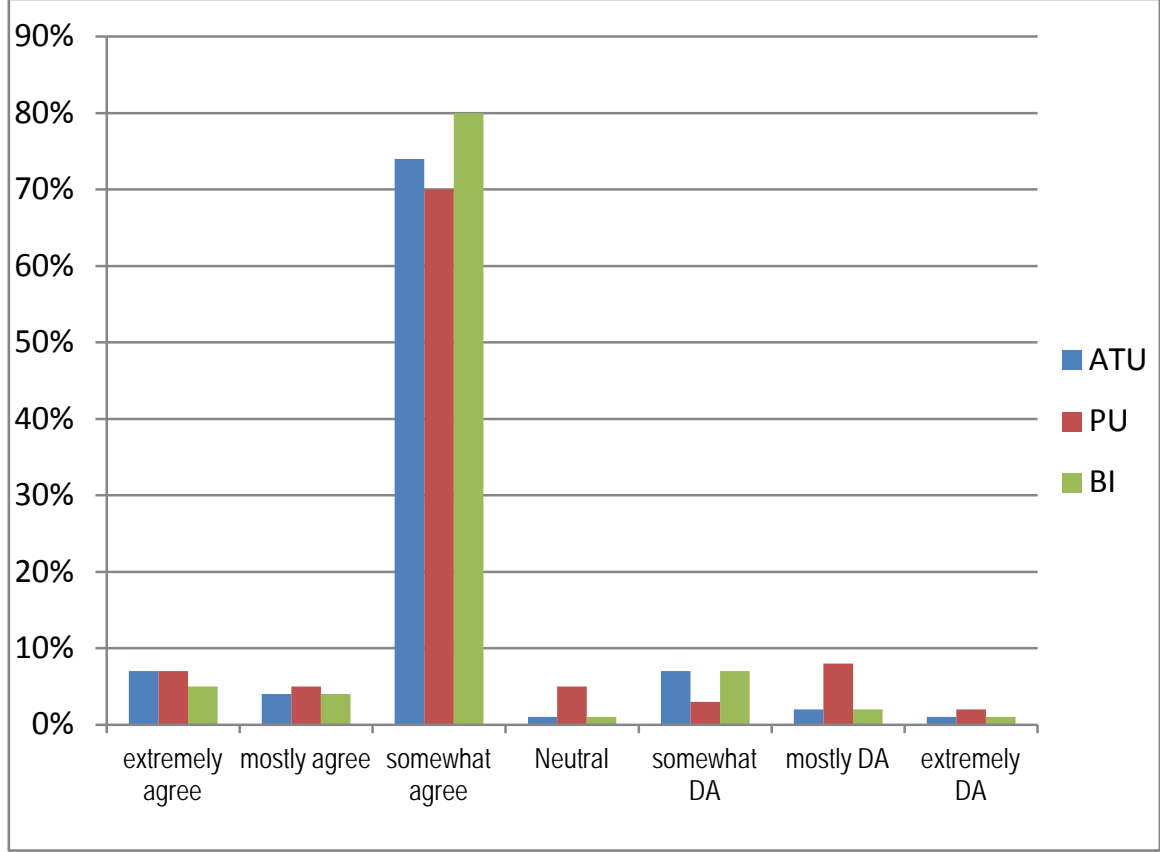

Figure 10.

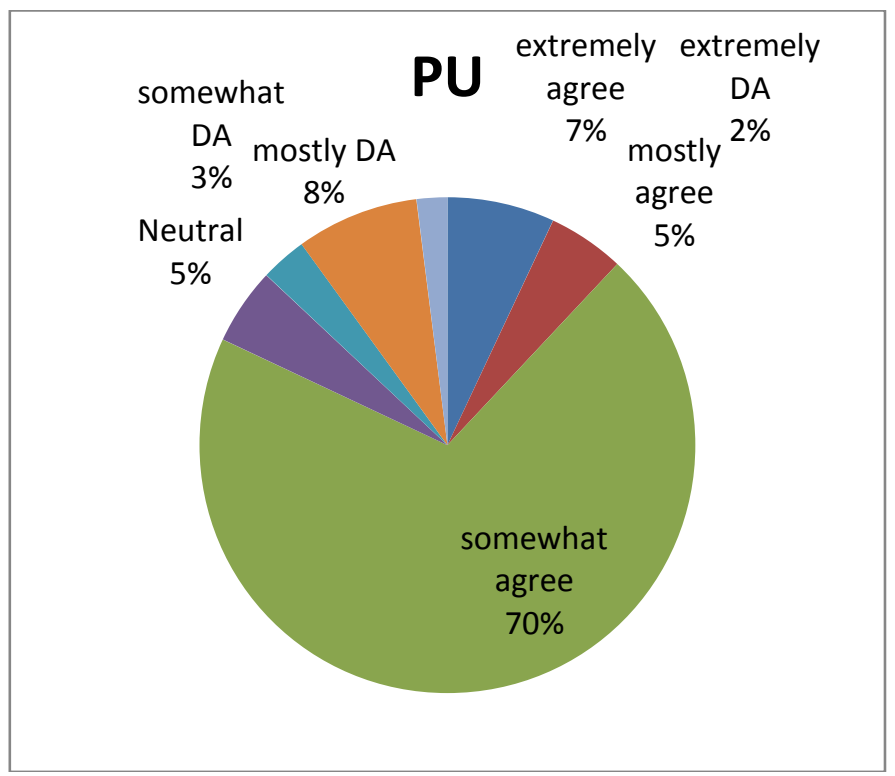

Figure 11. Participants' responses on four items of PU 


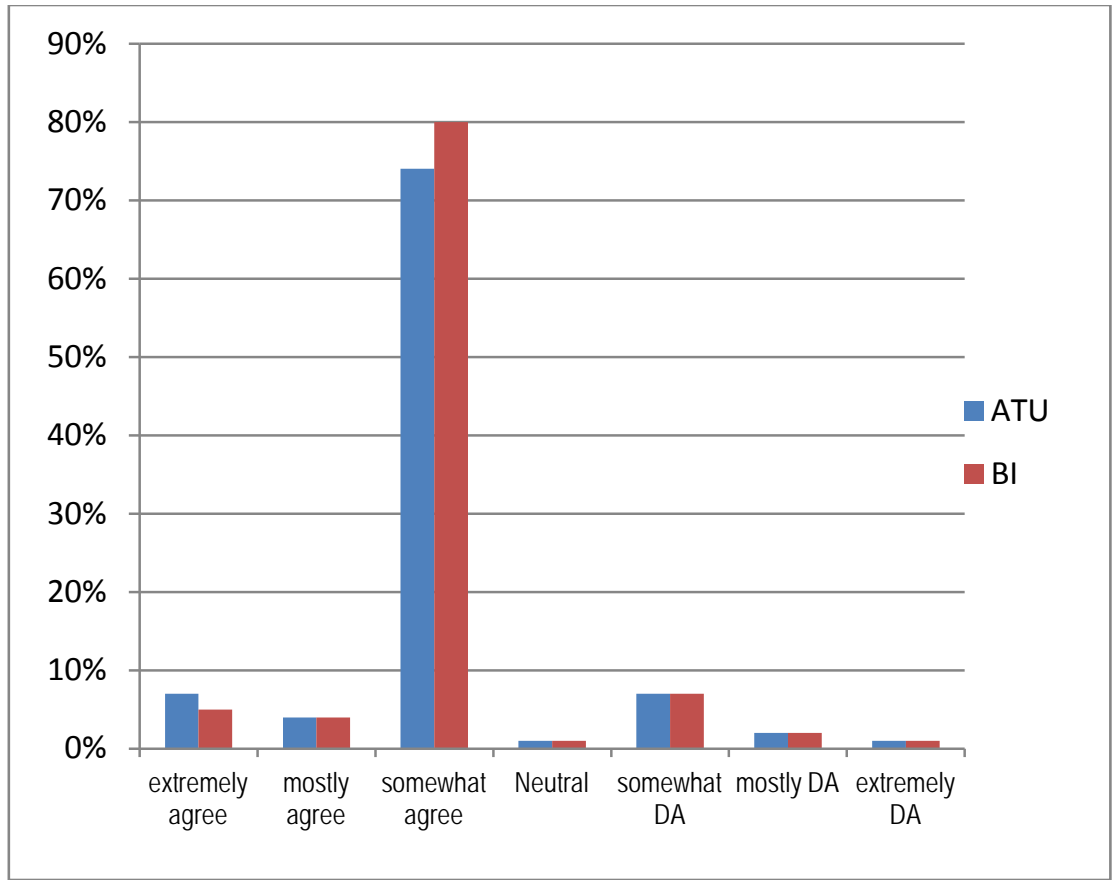

Figure 12.

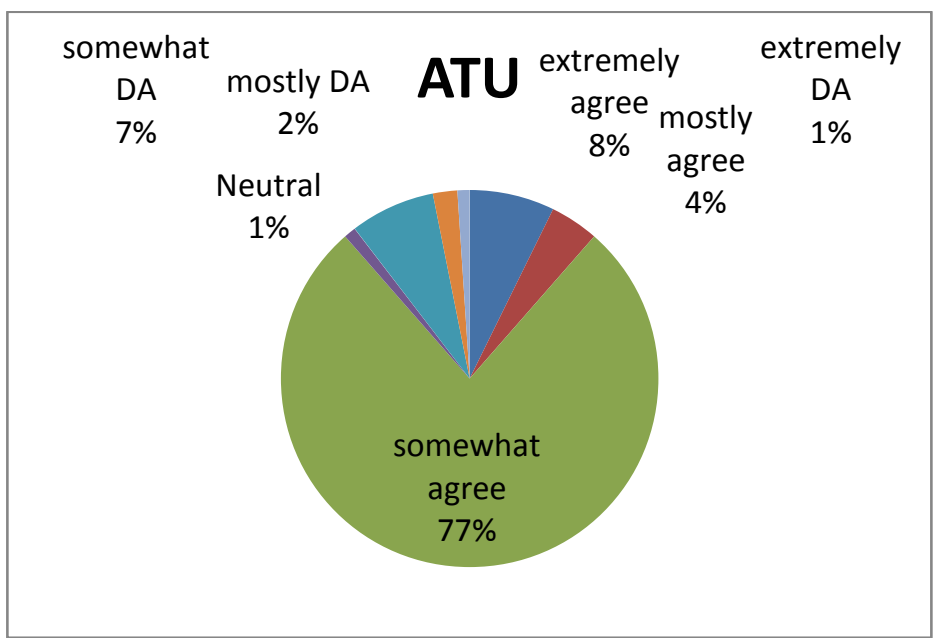

Figure 13. Participants’ responses on two items of ATU

High positive responses in attitude towards use (ATU) were moved towards high positive responses in behavioral intention (BI). Researcher 
found that mostly teachers had shown positive attitude towards use (ATU) and behavioral intention (BI) to use technology in spite of it they could use technology efficiently or not.

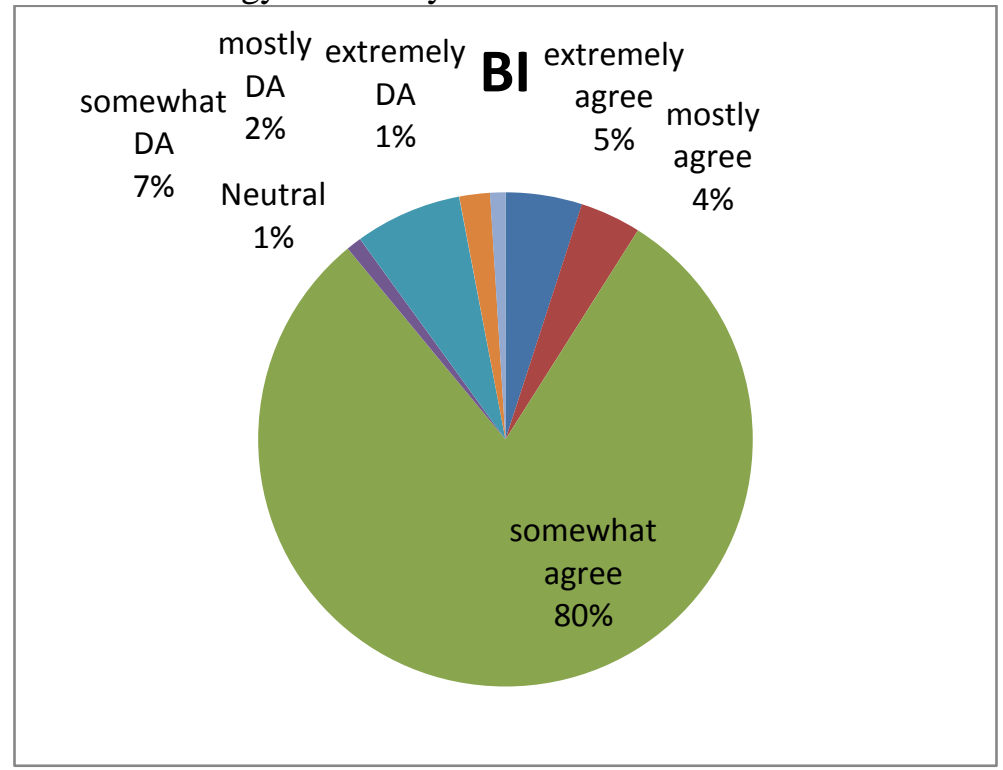

Figure 14. Participants' responses on two items of BI

Comparison between responses of male participants and female participants on all constructs of research model showed that there was no particular difference on the bases of Gender due to having almost same academic qualifications and professional training.(Figure 15,16) Furthermore they were all involved their teaching practices in learning environments having almost same infrastructures of organizations. Anyhow participants of thrice age groups respond different of both genders, first age group ranged from 25 years to 35 years responded more positively than second age group ranged from 35 years to 45 years and second age group responded more positively than third age group ranged from 45 years to 55 years. Third age group participants responded more in neutral or categories of disagreement showing low acceptance of technology in their teaching practices.

The participants of first age group (25 to 35) had shown more positive responses on all constructs of model except facilitating conditions (FC) as compare to second age group. Almost they were all having high academic qualification with computer skills, mostly were 
newly recruited and facilitated with induction training included computer training also. Their students' responses were quite positive on the question, "whether your teacher can use technology efficiently or not”.

The participants of second age group (35 to 45) had shown more positive responses in constructs of perceived usefulness (PU), attitude towards use (ATU) and behavioral intention (BI). When they were observed during their teaching practices, they were facing difficulties to integrate technology in learning process due to lack of computer trainings. Their students responses were mixed showing that some of them could use technology mostly, some of them merely and some of them hardly. So there is great need to facilitate such teachers with trainings and organization infrastructure to use technology in teaching practices.

The third age group (45 to 55) as discussed above had shown more neutral or negative responses on all constructs of model. During the observations of their teaching practices and from interviews of their students, the researcher found that mostly teachers regardless their gender, were showing almost similar attitude of low acceptance towards use of technology, so researcher suggested providing counseling therapy to the teachers of such age group towards use of technology. More than twenty percent workforce of teachers is belonging to this age group, showing mostly technology aversions or disharmony which would be created problems to integrate technology in their teaching practices not only in present but also in coming years. Most of the students are more efficient in use of technology than their teachers belonging to this age group specially. During interview their expressions were quite negative in the response of question about their teachers' efficient use of technology. 


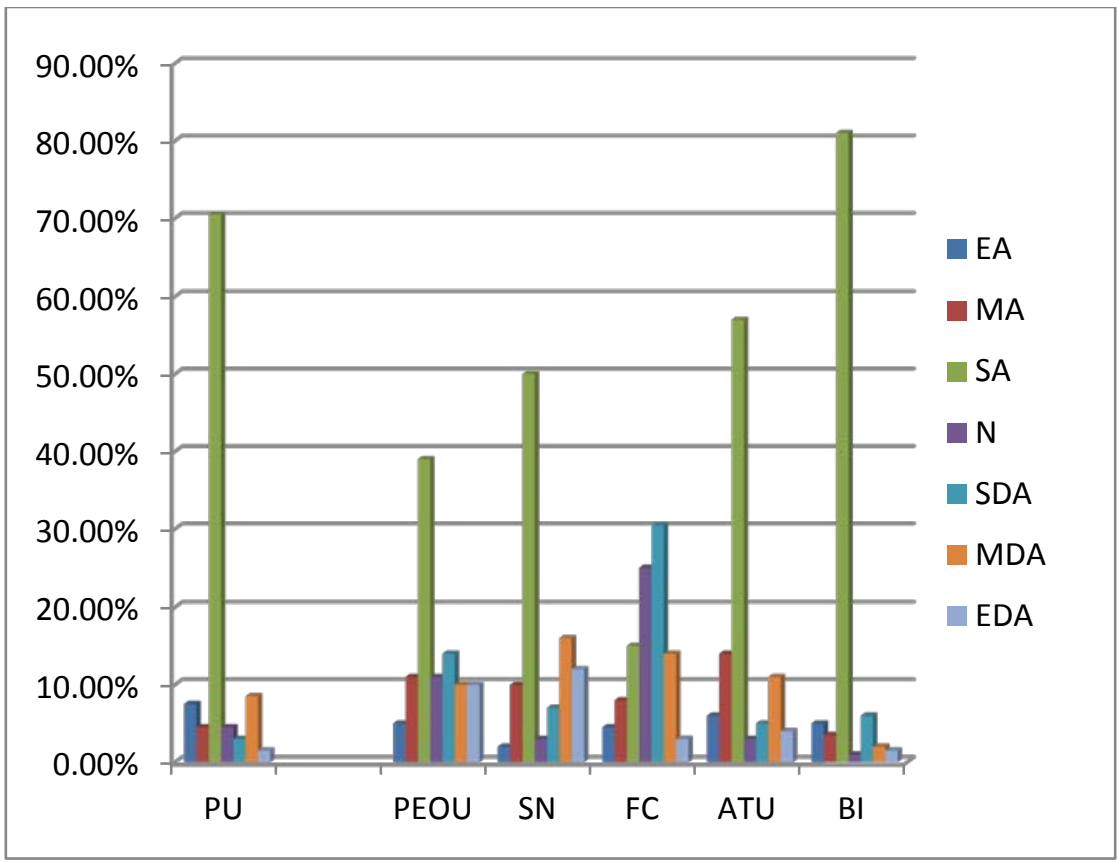

Figure 15. Female responses

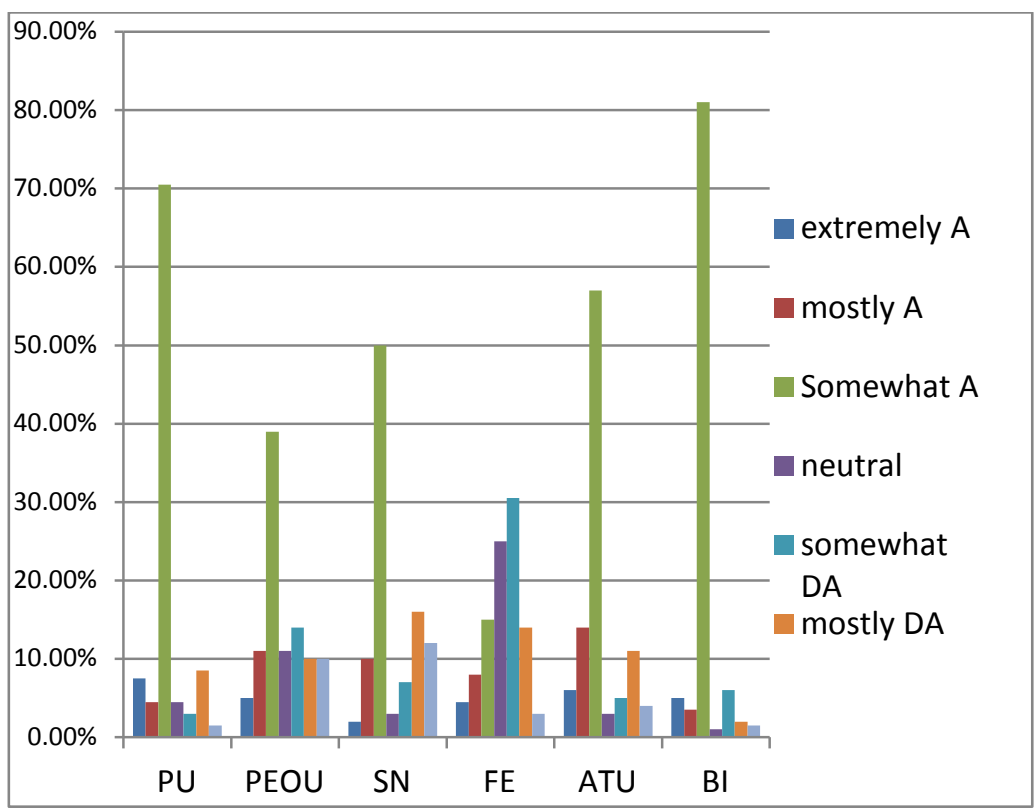

Figure 16. Male responses 


\section{Conclusion}

The researcher concluded from this study that technology acceptance model had great scope of application among teaching practices of secondary school teachers in Pakistani context. This study proved that perceived usefulness (PU) had played more significant role in developing attitude towards use (ATU) and behavioral intention (BI) rather than perceived ease of use (PEOU). While Technical infrastructure and skilled assistance were required more to facilitate teachers at secondary level in Pakistan to use and integrate technology in teaching practices. In spite of IT labs are functional in all secondary schools having fifteen computers and one IT expert each, but there is no availability of multimedia and computers in classrooms, so teachers are facing problems to integrate technology yet having high behavioral intention to use technology in learning process.

To involve students more and more in learning process, there is great need to use technology in classrooms due to spreading fast and updated knowledge through it. Teachers belonging to age group ranged from 45 years to 55 years are required to counsel them in the favor of use of technology in teaching practices. Now in this century technology has become an ocean of innovations, so teachers of all age groups are required technical trainings repeatedly due to introducing fast innovations in technology day by day. Furthermore this study in Pakistan is an addition in related literature and researches. In future studies more external variables can be added to apply this technology acceptance model.

\section{References}

Ajzen, I. (1991). The theory of planned behavior. Organizational Behavior and Human Decision Process, 50, pp. 179-211.

Ajzen, I. (1988). Attitudes, Personality and Behavior. Dorsey Press, Chicago

Bliss, J., Chandra, PAJ., \& Cox, M.J. (1986) The Introduction of Computers into a School. Advances in Computer Assisted Learning. Pergamon.

Cox, M. J, Rhodes, V. \& Hall, J. (1988) The use of Computer Assisted Learning in primary schools: some factors affecting the uptake. Computers and Education. Vol. 12(1). pp. 173-178. 
Cox, M.J, (1993) Information Technology Resourcing and Use in Watson, D.M. (Ed.) Impact - An evaluation of the Impact of the Information Technology on Children's Achievements in Primary and Secondary Schools. King's College London

Cox, M.J. (1994) An overview of the Problems and Issues associated with the Uptake of Computers in the United Kingdom Education Institutions in Visions for Teaching and Learning. Educomp 94 Proceedings. Malaysian Council for Computers in Education. June pp 233 - 247.

Cox, M.J., Preston, C., \& Cox, K. (1999) What Motivates Teachers to use ICT?. Paper presented at the British Educational Research Association Conference. Brighton. September

Davis, F.d, Bagozzi, R.P \& Warshaw, P.R. (1989) User acceptance of computer technology: a comparison of two theoretical models. Management Science. Vol. 35(8). 982-1003

Davis, F. D., (1993). User acceptance of information technology: system characteristics, user perceptions and behavioral impacts. International Journal of Man-machine Studies, 38(3), pp.475-487.

Fishbein, M., \& Ajzen, I. (1975). Belief, attitude, intension and behavior: An introduction to theory and research. Reading, MA: Addison Wesley.

Ismail, S.A.A., Almekhlafi, A.G., \& Al-Mekhlafy, M.H. (2010) Teachers $^{\text {ee }}$ perceptions of the use of technology in teaching languages in United Arab Emirateš schools. International Journal for Research in Education (IJRE), NO. 27. 37-55

Jones, A. (2012). Teacher perceptions and Use of ICT in Unfamiliar Classroom Situations. CICTE 2012 Proceedings. 314-322 Kriek, J. \& Stols, G. (2010). Teacheirsbeliefs and their intention to use interactive simulations in their classrooms. South African Journal of Education. Vol. 30:439-456

Lawrence, S.A., \& Calhoun, F. (2013). Exploringe Teachers Perceptions of Literacy and Use of Technology in Classroom Practice: Analysis of Self-Reported Practice in One School District. Journal of Literacy and Technology. 14(1).51-71 
Ma,Q \& Liu, L (2004). “The technology Acceptance Model: A metaAnalysis of Empirical Findings”. Journal of Organizational and End User Computing. 16(1), 59-72.

Schneberger, S. Amoroso, D.L. \& Durfee, A. (2008). Factors that influence the performance of computer-based assessments: an extension of the Technology Acceptance Model. Journal of Computer Information Systems, 48(2), p.74.

Taylor, \& Todd, “Assessing IT usage: The role of prior experience.” MIS Quarterly, vol. 19, no. 4, 1995, pp. 561-570.

Tella, A., Toyobo, O. M., Adika, L. O., \& Adeyinka, A. A. (2007). An Assessment of Secondary School Teachers Uses of ICTs: Implications for Further Development of ICT's Use in Nigerian Secondary Schools. Online Submission, 6(3).

Venkatesh, V., Morris, M. G., Davis, G. B., \& Davis, F. D. 2003. "User Acceptance of Information Technology: Toward a Unified View," MIS Quarterly (27:3), pp. 425-478.

Venkatesh,\& Davis, “A theoretical extension of technology acceptance model: Four longitudinal field studies.” Management Science, vol. 46, no. 2, 2000, pp. 186-204.

Wong, K.T., Osman, R., Goh, P. S. C., Rahmat, M.K., (2013). Understanding Student Teachers Behavioural Intention to Use Technology: Technology Acceptance Model (TAM) Validation and Testing. International Journal of Instruction, 6(10), 89-104

Wozney, L., Venkatesh, V. \& Abrami, P. (2006). Implementing Computer Technologies: Teachêfs Perceptions and Practices. Journal of Technology and Teacher Education. 14(1), 173-207. Information Technology. supporting change through teacher education. Chapman \& Hall. pp 155 - 160.

Watson, D.M. (Ed.) (1993) IMPACT - An evaluation of the IMPACT of the Information Technology on Children's Achievements in Primary and Secondary Schools. King's College London

Weiner, B (1990) The History of Motivational Research. Journal of Educational Psychology Vol. 82. (4) 616-627 
Woodrow, J. (1990) Locus of Control and student teacher computer attitudes. Computers Education. Vol. 14. No. 4 pp 421-432

\section{Web-based References}

Ajda K, \& Neşe, S. (2011). Computer Perceptions of Secondary School Teachers and Impacting Demographics: A Turkish Perspective retrieved from www.tojet.net/articles/v10i1/1017.pdf dated 18/6/14

Sadiq A, Ahmed I, Abdurrahman, \& Ghaleb A. ( 2010). Teachers' perceptions of the use of technology in teaching languages in United Arab Emirates' schools retrieved from www.cedu.uaeu.ac.ae/en/research innovation/journal/pdf/pdf27/ 7.pdf dated 10/8/14

Ayşe Aypay, Halil Coşkun, Çelik Siirt Ahmet \& Aypay. (2012). Technology Acceptance in Education: A Study of Pre-Service Teachers in Turkey http://www.tojet.net/articles/v11i4/11426.pdf retrieved dated 15/7/14

Doris Choy Angela, F. L Wong\& Ping Gao. (2009). Student Teachers' Intentions and Actions on Integrating Technology into Their Classrooms during Student Teaching: A Singapore study http://edtltechintegrate.bgsu.wikispaces.net/file/view/Actions+to+In tegrating+tech.pdf retrieved 25/6/14

Lincoln G. \& Barney D. (2008). Influences on pre-service teachers' preparedness to use ICTs in the classroom. http://www.ascilite.org.au/ conferences/melbourne08/procs/gill.pdf retrieved dated 15/8/14

Samuel Nii, Boi Attuquayefio, \& Akwasi Kyere. (2014). Extending Tam with Social Norm to Model Students' intentions To Adopt ICT retrieved from eujournal.org/index.php/esj/article/d 